UDC 658.15:005.52

DOI: $10.15673 /$ fie.v11i3.1460

\author{
Kuprina $\mathbf{N}$. \\ Ph.D., Associate Professor \\ Department of Accounting and Auditing \\ E-mail:k.natali_@ukr.net \\ ORCID ID: 0000-0003-4645-545X
}

\author{
Volodina O. \\ Assistant \\ Department of Foreign Languages \\ E-mail: completeness7@mail.ru
}

\author{
Zavatska Yu. \\ 2nd year student with short term Bachelor's degree \\ Odesa National Academy of Food Technologies \\ Kanatna str., 112, Odesa, Ukraine, 65039 \\ E-mail: juliaz2317@gmail.com
}

\title{
FEATURES OF THE ANALYSIS OF FINANCIAL RESULTS OF THE ENTERPRISE ACTIVITIES IN MODERN CONDITIONS
}

The article examines the approaches to the methodology of conducting financial results of the enterprise in scientific works and papers that have a practical focus, as well as in accordance with national and international Accounting Regulations (standards), which control the order of their formation and reflection in the financial statements.

The financial results of the activity of the enterprise according to the materials of the financial statements of the food industry enterprise for three years have been analyzed with the factor analysis of the financial results using the additive model. The application of the complex methodical approach to the analysis of financial results of the enterprise activity, which covers the analysis of the composition, structure, dynamics of incomes and expenses of the enterprise, the analysis of the formation, structure and dynamics of changes in the financial results of the enterprise, both in general and by individual types, the factor analysis of the financial results formation with the use of the additive model, taking into account the factors of the first, second and third order, the analysis of profitability (products, prodaction, capital) of the company, allowing to develop increase of positive trends as fo its financial results, have been offered.

Keywords: financial results of the enterprise activity, types of enterprise activity, profit, loss, methodology of the economic analysis, factor analysis, additive factor model, complex methodical approach.

This work is licensed under a Creative Commons Attribution 4.0 International License http://creativecommons.org/licenses/by/4.0/

Statement of the problem and its connection with important scientific and practical tasks. The main purpose of the enterprise, as well as any business entity, is to obtain the ultimate financial result, i.e. the profit. The financial result, namely the profit, is one of the key indicators of its effectiveness in today's global economic transformation, and the definition of the concept of financial results is an important scientific problem and remains in the focus of scientists not only in accounting, but also economic theory, microeconomics, macroeconomics, finance, management and economic analysis and contains many contradictions that make its research relevant. The value of a positive financial result is the stock of financial stability, so the issues of the qualitative economic analysis and formation monitoring are relevant and require additional research.

The analysis of the latest publications on the problem. Research of methods of analysis of financial results and significant contribution to their decision have been made by such economists as: Antoniuk O.P., Bilyk M.S., Bilyk M.D., Boliukh M.A., Voronko O.S., Goritskaya N.G., Hrabovetskyi B.Ye., Zahorodnii A.H., Kin- dratska H.I., Kovalchuk I.V., Lytvyn B.M., Metz V.A., Mnykh Ye.V., Nevmerzhitskaya M.Yu., Pavlovskaya O.V., Prytulyak N.N., Stelmakh M.V., Stupnitskaya TM, Tarasenko N.V., Terepenchuk V.V., Tsal-Tsalko Yu.S., Cherep A.V., Chernelevsky L.M., Chernysh S.S., Chumachenko MG, Shvarts I.V., Sheremet O.O., Shtepa N.P. and others, but these issues are debatable nowadays and require research related to changing the environment and ensuring the efficiency of businesses. One of the aspects of confirming the relevance of the research is the need to form an approach that facilitates the effective economic analysis of the financial results of the enterprise to further monitor it and ensure the increase of the positive financial result.

Forming of the aims of the research. The purpose of the article is to study approaches to conducting economic analysis of the financial results of the enterprise in scientific works and formation of the financial result in accordance with the NP (C) BO 1 and $\mathrm{M}(\mathrm{C}) \mathrm{BO} 1$ and formation of the complex approach of the economic analysis implementation of the financial result of the enterprise activity taking into ac- 
count modern conditions of its functioning and ensuring the effectiveness of its activities.

Giving an account of the main results and their substantiation. The financial result of the enterprise activity (profit or loss) is formed mainly from the financial result from the main operating activities. The profit from the sale of products (works, services) from the main operating activities of the enterprise is the main part of the financial result of the enterprise activity and is defined as the difference between the net income (revenue) from the sale of products (goods, works, services) and the cost of sales (goods, works, services), the value of administrative and sales costs, namely gross profit - as the difference between the net income (revenue) from sales of products (goods, works, services) and the cost of sales (goods, works and services).

The assessment and analysis of operating income is performed on the basis of the indicators contained in Form No. 2, «Statement on Financial Results (Statement on comprehensive income)» by comparing the relevant indicators of the reporting and previons periods to determine their changes, dynamics and trends [24], in accordance with IFRS 1 «Presentation of Financial Statements», this form is called «Statement of on comprehensive income» [25].

According to NP (C) BO 1, «General Requirements for Financial Reporting» include only a definition of such concepts as «statement on financial performance», «profit» and «loss» [24], that is what causes the uncertainty of the nature and significance of financial results. Thus, according to $\mathrm{NP}(\mathrm{C}) \mathrm{BO} 1$, profit is the amount by which the revenue exceeds its associated costs, and the loss is the excess of the amount of expenses over the amount of incomes for which these expenses are implemented [24].

The study showed that by analyzing the composition of IAS 1 and IAS 1 , a comparative characterization of the stages of formation of the final result (profit or loss) can be made (Fig. 1), respectively.

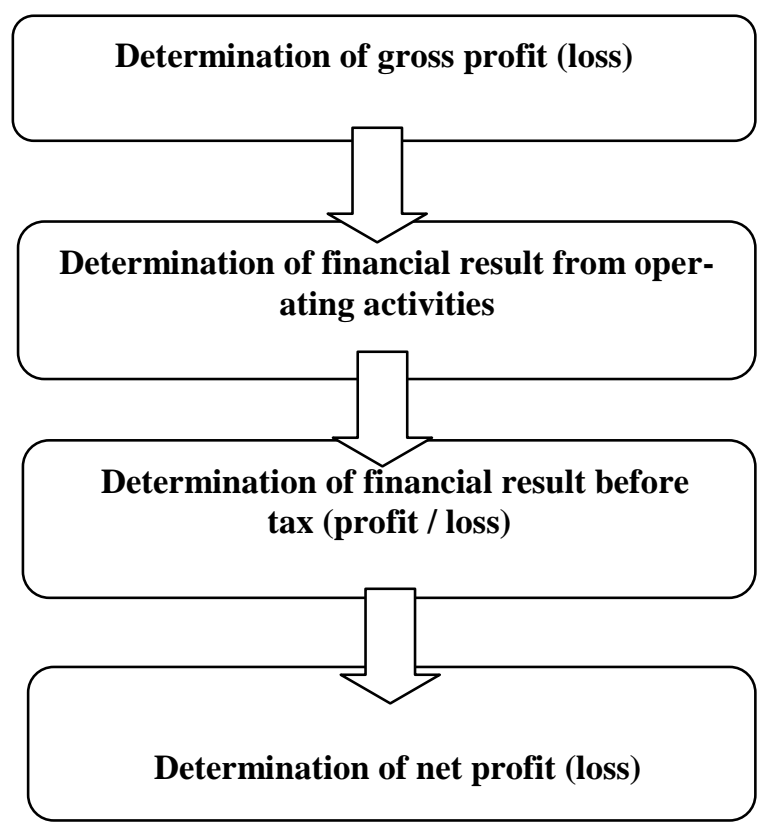

Fig. 1. Stages of formation of the end result of the enterprises activity in accordance with IAS 1 and IAS 1 respectively *

* compiled by the author on the basis of sources [24-25]

The study of IAS 1 and IAS 1 has shown that the stages of formation of the final result (profit or loss) according these regulatory documents differ, but in Ukraine the process of harmonization of national regulatory documents controlling the accounting, and financial reporting preparation with international ones takes place, which is a positive trend.

As the research has shown, profits from the sale of products (works, services), namely its value, depend on many factors, such as the change in the cost of production and sales, decrease (or increase) in the volume and range of sales and change in the price of products, change of administrative and sales costs and their structure. According to Mochernyi S.V., in order to identify the value of these factors, it is necessary to directly recalculate the indicators of income from the sale of the actual volume of production at the prices of realization of the base period [1].

The economic analysis of the financial results of the enterprise, as shown by the study of scientists, aimed at studying their dynamics, composition and structure both as a whole in the enterprise, and by individual types of its activity, but most authors [1417] pay attention to the analysis of financial results from the main operating activities, but also financial results from the financial, investment and other activities of the enterprise have a significant impact on the financial performance of the enterprise have and can lead to its negative value.

Carrying out of economic analysis of the 
financial results of the enterprise activity involves use of a certain methodology as a set of rules, techniques and methods of studying and processing of financial information [19].

As the research showed, the main methods of the analysis of the financial condition of the enterprise are: the horizontal analysis (in the process of the analysis, absolute and relative changes in the values of balance sheet items over the reporting period have been calculated); vertical analysis (consists of calculating the proportion of individual items in the balance sheet currency, i.e. studying of the structure of the balance sheet at the beginning and end of the period); coefficient analysis (is used to calculate the level and dynamics of the relative indicators of financial condition) and factor analysis (it helps to identify the reasons for the change in absolute and relative financial indicators and to calculate the influence of factors on the change in the financial indicator) [3] (Table 1).

Table 1

Comparison of approaches to the method of the economic analysis of financial performance *

\begin{tabular}{|c|c|c|c|c|c|c|c|c|c|c|c|}
\hline Author & 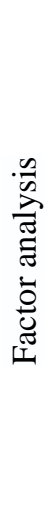 & 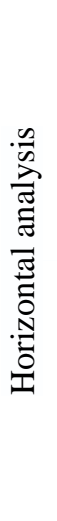 & 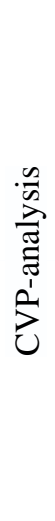 & 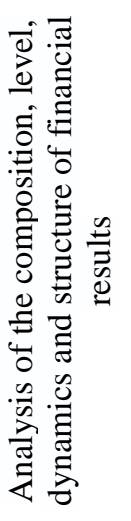 & 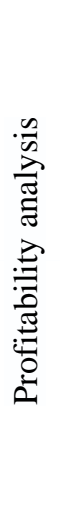 & 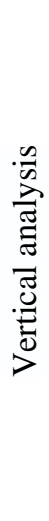 & 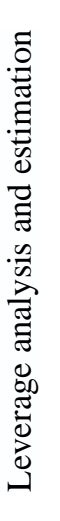 & 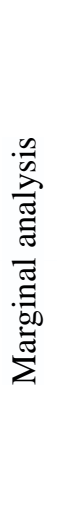 & 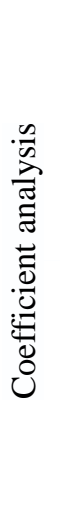 & 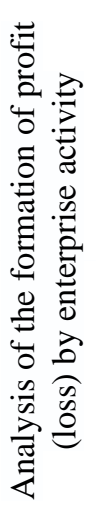 & 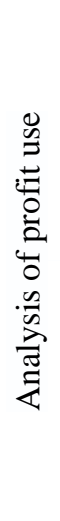 \\
\hline $\begin{array}{l}\text { 1. Voronko O.S., } \\
\text { Shtepa N.P. }\end{array}$ & + & & + & & + & & & + & & & + \\
\hline $\begin{array}{l}\text { 2. Antoniuk O.P., } \\
\text { Stupnytska T.M., } \\
\text { Kuprina N.M. }\end{array}$ & + & + & & & + & + & & & + & + & \\
\hline $\begin{array}{l}\text { 3. Hrabovetskyi B.Ye., } \\
\text { Shvarts I.V. }\end{array}$ & & & & + & + & & + & & & + & \\
\hline $\begin{array}{l}\text { 4. Lytvyn B.M., } \\
\text { Stelmakh M.V. }\end{array}$ & + & & & + & + & & & & & + & \\
\hline $\begin{array}{l}\text { 5. Boliukh M.A., } \\
\text { Burchevskyi V.Z., } \\
\text { Horbatiuk M.I. }\end{array}$ & + & + & & & + & + & & & + & & \\
\hline 6. Chernysh S.S. & & & & & + & & + & & & + & + \\
\hline $\begin{array}{l}\text { 7. Mnykh Ye.V., } \\
\text { Barabash N.S. }\end{array}$ & + & & & + & + & & + & & & + & + \\
\hline 8. Kovalchuk I.V. & & & & & + & & & & & + & \\
\hline $\begin{array}{l}\text { 9. Kindratska H.I., } \\
\text { Bilyk M.S., } \\
\text { Zahorodnii A.H. }\end{array}$ & + & + & & & + & + & & & + & + & \\
\hline $\begin{array}{l}\text { 10. Bilyk M.D., } \\
\text { Nevmerzhitskaya M.Yu., } \\
\text { Pavlovskaya O.V., } \\
\text { Prytulyak N.N. }\end{array}$ & + & + & & & + & + & & & & & \\
\hline
\end{tabular}

*systematized by authors on the basis of [4-13]

The analysis of scientists' work on the method of the economic analysis of the financial results of the enterprise confirms that:

1. The most used direction in the methodology of analysis is the analysis of profitability, in the second place - the analysis of the formation of profit (loss) of activity and the third - the factor analysis.

2. Horizontal analysis, analysis of composition, level, dynamics and structure of financial results, vertical analysis, analysis and evaluation of leverage, coefficient analysis and analysis of the use of profit are widely used in practice and are considered in the works of domestic scientists.

3. The least used direction in the method of economic analysis of financial results is the method of marginal analysis and CVR analysis, which is described by the authors Voronko O.S. and Shtepa N.P. 
4. Most scientists analyze, as a rule, the financial result from the main operating activities, which is not appropriate, because the positive financial result from this type of activity may be reduced at the expense of losses from other activities of the enterprise.

Therefore, the given study confirmed the need to analyze the financial results using a comprehensive methodological approach, which is effective in the modern practical activity of enterprises:

1. The analysis of the composition, structure and dynamics of income of the enterprise, namely [5]:

- a general estimate of the income that the enterprise makes in the course of its activity;

- analysis of the dynamics and formation of income, which the enterprise carries out in the course of the main operating activity;

- analysis of the composition, dynamics and structure of other operating incomes;

- analysis of the composition, dynamics and structure of financial incomes;

- analysis of the composition, dynamics and structure of income from participation in equity by investments;

- analysis of the composition, dynamics and structure of other income.

2. The analysis of the composition, structure and dynamics of costs of the enterprise, namely [5]:

- an overall estimate of the costs incurred by an enterprise in the course of its activity;

- analysis of the dynamics and cost structure that the company carries out in the course of the main operating activity;

- analysis of the composition, dynamics and structure of other operating expenses;

- analysis of the composition, dynamics and structure of financial expenses;

- analysis of the composition, dynamics and structure of losses from participation in capital of investments;

- analysis of the composition, dynamics and structure of other costs;

- analysis of expenses from the activity of the enterprise for 1 hryvnia of operating income;

3. The analysis of the formation, structure and dynamics of changes in the financial results of the enterprise, namely [21]:

- general analysis of the composition, dynamics and structure of financial results of the enterprise;

- analysis of formation and dynamics of financial results of the enterprise from the main operating activity;

- a detailed analysis of the formation, dynamics and structure of financial results from other operating activities;

- a detailed analysis of the formation, dynamics and structure of financial results from investment activities;
- a detailed analysis of the formation, dynamics and structure of financial results from financial activities;

- analysis of formation and use of profit of the enterprise.

4. The analysis of the formation of financial results using the additive model [23]:

- analysis of the first-order factors (corresponding income and expenses from a certain type of activity);

- analysis of second-order factors (detailing of the factors of the first order: income and expenses from a certain type of activity. For example, the costs from the main operating activities are divided into the cost of sales, administrative costs, sales costs);

- analysis of third-order factors (second-order item detailing: income and expenses by individual items and their detailing) $[12,23]$.

5. The analysis of profitability $[5,22]$ :

- analysis of profitability of sold products;

- profitability analysis of individual products;

- analysis of production profitability;

- analysis of return on equity.

As the study showed, it is profitability analysis that is most used in the methodology of analyzing the financial results of an enterprise, which is understandable, since profitability is a relative indicator that reflects the efficiency of the enterprise functioning and its capital and costs incurred. In the domestic and western accounting and analytical theory, three indicators of estimation of profitability of products are used, depending on the indicator of financial result, which is the basis of calculation: indicators of gross, operating and net profit. According to them, similar indicators of profitability are calculated: gross profitability (ratio of the amount of gross profit to the value of net income from sales of products), operating profitability (ratio of the amount of profit from operating activities to the value of net income from sales of products) and net operating profitability of products (ratio of net operating income from the sale of products (minus of income tax) to the amount of net income from the sale of products [5].

Thus, examining approaches to economic analysis of financial results of operations, in our opinion, we can say thet such analysis can not be limited only by factor analysis or profitability analysis, because each of the absolute or relative indicators gives the necessary information about the financial condition of the enterprise and the effectiveness of its functioning, therefore, having the most comprehensive set of indicators and using a comprehensive combined method of such analysis will give the most complete picture of the current situation of the enterprise and its future possibilities.

Based on the basis of the data of Form No. 2 «Financial Statement (Total Income Statement)» of Form No. 5 «Notes to the Annual Financial Report», we consider several directions of the combined methodological approach to its implementation on the example of the food industry (Table 2-4). 
Table 2

Analysis of financial composition, dynamics and structure of financial results of the enterprise activity*

\begin{tabular}{|c|c|c|c|c|c|c|c|c|c|}
\hline \multirow{2}{*}{ Indicators } & \multirow{2}{*}{$\begin{array}{l}\text { Algorithm } \\
\text { of calculation } \\
\text { by the code } \\
\text { of the row }\end{array}$} & \multicolumn{2}{|c|}{2015 year } & \multicolumn{2}{|c|}{2016 year } & \multicolumn{2}{|c|}{2017 year } & \multicolumn{2}{|c|}{$\begin{array}{c}\text { Deviation } \\
2017 \text { from } 2016\end{array}$} \\
\hline & & $\begin{array}{l}\text { thousand } \\
\text { UAH }\end{array}$ & $\%$ & $\begin{array}{l}\text { thousand } \\
\text { UAH }\end{array}$ & $\%$ & $\begin{array}{l}\text { thousand } \\
\text { UAH }\end{array}$ & $\%$ & $\begin{array}{l}\text { thousand } \\
\text { UAH }\end{array}$ & $\%$ \\
\hline $\begin{array}{l}\text { 1. The financial result } \\
\text { from the sale of } \\
\text { products }\end{array}$ & $\begin{array}{l}2000-2050- \\
2130-2150\end{array}$ & -7976 & 50,6 & -14040 & 91,8 & -17196 & 244,4 & -3156 & $-22,48$ \\
\hline $\begin{array}{l}\text { 2. The financial result } \\
\text { from other operating } \\
\text { activities }\end{array}$ & $2120-2180$ & -7782 & 49,4 & -1196 & 7,8 & -39 & 0,5 & 1157 & $-96,74$ \\
\hline $\begin{array}{l}\text { 3. The financial result } \\
\text { from operating } \\
\text { activities }\end{array}$ & $2190(2195)$ & -15758 & $\mathrm{x}$ & -15302 & $\mathrm{x}$ & -7044 & $\mathrm{x}$ & -8258 & $-53,97$ \\
\hline $\begin{array}{l}\text { 4. The financial result } \\
\text { from investment and } \\
\text { financial activities }\end{array}$ & $\begin{array}{l}2200+2220- \\
2250-2255\end{array}$ & - & - & - & - & - & - & - & - \\
\hline $\begin{array}{l}\text { 5. The financial result } \\
\text { of other activities }\end{array}$ & $2240-2270$ & -9 & 0,1 & -61 & 0,4 & 10198 & $-144,9$ & 10259 & 100,60 \\
\hline $\begin{array}{l}\text { 6. The financial } \\
\text { results before tax }\end{array}$ & $2290(2295)$ & -15767 & 100,0 & -15297 & 100 & -7037 & 100 & 8260 & 17,40 \\
\hline
\end{tabular}

* calculated by the authors on the basis of financial statements

The conducted analysis showed that the financial result of the activity of the enterprise for 20152017 was mainly formed at the expense of loss from sale of products, which tends to increase, which negatively characterizes both the main operating activity of the enterprise and other operating one which is unprofitable for the period that is being analyzed. But the loss from other operating activities for 2015-2017 tends to decrease, which is positive. The financial result of the enterprise - loss decreased in 2017 compared to 2016 by
$117,4 \%$ due to the increase in profit from other activities of the enterprise by 10259 thousand UAH. or $100,6 \%$, which positively influenced the formation of the overall financial result of the activity.

The analysis of the dynamics and formation of the financial result from the main operating activities is carried out using the indicators of the form No. 2 «Statement on financial results (Statement on comprehensive income)» (Table 3).

Table 3

Analysis of the formation and dynamics of financial results of the enterprise from the main operating activity*

\begin{tabular}{|c|c|c|c|c|c|c|}
\hline \multirow{2}{*}{ Indicators } & \multirow{2}{*}{$\begin{array}{l}\text { Algorithm } \\
\text { calculation } \\
\text { by the code } \\
\text { of the row }\end{array}$} & \multirow{2}{*}{$\begin{array}{c}2015 \text { year, } \\
\text { thousand } \\
\text { UAH }\end{array}$} & \multirow{2}{*}{$\begin{array}{c}2016 \text { year, } \\
\text { thousand } \\
\text { UAH }\end{array}$} & \multirow{2}{*}{$\begin{array}{c}2017 \\
\text { year, } \\
\text { thousand } \\
\text { UAH }\end{array}$} & \multicolumn{2}{|c|}{$\begin{array}{c}\text { Deviation } \\
2017 \text { from } 2016\end{array}$} \\
\hline & & & & & $\begin{array}{l}\text { thousand } \\
\text { UAH }\end{array}$ & $\%$ \\
\hline $\begin{array}{l}\text { 1. Net income from sales of prod- } \\
\text { ucts (goods, works, services) }\end{array}$ & 2000 & 95549,0 & 48156,0 & 11075,0 & $-37081,0$ & $-77,00$ \\
\hline 2. Cost of sales & 2050 & 88238,0 & 47335,0 & 16391,0 & $-30944,0$ & $-65,37$ \\
\hline 3. Administrative costs & 2130 & 12290,0 & 13319,0 & 11165,0 & $-2154,0$ & $-16,17$ \\
\hline 4. Sales costs & 2150 & 2997,0 & 1542,0 & 715,0 & $-827,0$ & $-53,63$ \\
\hline $\begin{array}{l}\text { 5. The financial result from the } \\
\text { main operating activities }\end{array}$ & $\begin{array}{l}2000-2050- \\
-2130-2150\end{array}$ & $-7976,0$ & $-14040,0$ & $-17196,0$ & $-3156,0$ & $-22,48$ \\
\hline
\end{tabular}

* calculated by the authors on the basis of financial statements

The financial result from operating activities (loss) for 3 years tends to decrease, which is a positive trend and the presence of a loss from the main operating activity indicates the inefficient functioning of the enterprise and the negative performance of its activity. The factor analysis of the financial results of an enterprise using their additive model is a simple and effective tool to find directions for increasing the positive factors that have been identified and eliminate the impact of negative ones. So, the use of factor analysis by additive model - a technique of impact study, which is functional in nature, will allow to understand the logic of action of the main factors of enterprise development to quantify their impact, to understand what factors and in what proportion it is possible and advisable to change to increase the efficiency of the enterprise factors, the connection of which is effective [23] (Table 4). 
Table 4

Analysis of financial results from ordinary activity of the enterprise in absolute terms *

\begin{tabular}{|c|c|c|c|c|c|c|}
\hline \multirow[t]{2}{*}{ Indicators } & \multirow{2}{*}{$\begin{array}{l}2016 \\
\text { year, } \\
\text { thousand } \\
\text { UAH }\end{array}$} & \multirow{2}{*}{$\begin{array}{l}2017 \text { year, } \\
\text { thousand } \\
\text { UAH }\end{array}$} & \multicolumn{2}{|c|}{ Deviation } & \multicolumn{2}{|c|}{$\begin{array}{l}\text { Influence of factors on } \\
\text { change of financial re- } \\
\text { sults, thousand UAH. }\end{array}$} \\
\hline & & & $\begin{array}{l}\text { thousand } \\
\text { UAH }\end{array}$ & $\%$ & $\begin{array}{l}\text { change } \\
\text { income }\end{array}$ & $\begin{array}{l}\text { change } \\
\text { costs }\end{array}$ \\
\hline $\begin{array}{l}\text { 1. The financial result from the } \\
\text { main operating activities }\end{array}$ & -14040 & -17196 & -3156 & $-22,48$ & -37081 & -33925 \\
\hline $\begin{array}{l}\text { 2. Income from basic operating } \\
\text { activities }\end{array}$ & 48156 & 11075 & -37081 & -77 & -37081 & $\mathrm{x}$ \\
\hline $\begin{array}{l}\text { 3. Expenses from basic operat- } \\
\text { ing activities }\end{array}$ & 62196 & 28271 & -33925 & $-54,55$ & $\mathrm{x}$ & -33925 \\
\hline $\begin{array}{l}\text { 4. The financial result from } \\
\text { other operating activities }\end{array}$ & -1196 & -39 & 1157 & 96,74 & -892 & -2049 \\
\hline $\begin{array}{l}\text { 5. Income from other operating } \\
\text { activities }\end{array}$ & 2515 & 1623 & -892 & $-35,47$ & -892 & $\mathrm{x}$ \\
\hline $\begin{array}{l}\text { 6. Expenses from other operat- } \\
\text { ing activities }\end{array}$ & 3711 & 1662 & -2049 & $-55,21$ & $\mathrm{x}$ & -2049 \\
\hline $\begin{array}{l}\text { 7. Financial result from other } \\
\text { activities }\end{array}$ & -61 & 10198 & 10259 & в $-168,2$ p. & - & 10259 \\
\hline 8. Income from other activities & - & 10251 & 10251 & $\mathrm{x}$ & 10251 & $\mathrm{x}$ \\
\hline $\begin{array}{l}\text { 9. Expenses from other } \\
\text { activities }\end{array}$ & 61 & 53 & -8 & $-13,11$ & $\mathrm{x}$ & -8 \\
\hline $\begin{array}{l}\text { 10. Financial result from ordi- } \\
\text { nary activities before taxation }\end{array}$ & -15297 & -7037 & 8260 & $-53,99$ & -37973 & -36035 \\
\hline $\begin{array}{l}\text { 11. Income from activity be- } \\
\text { fore taxation, incl.: }\end{array}$ & 50671 & 12698 & -37973 & $-74,94$ & -37973 & $\mathrm{x}$ \\
\hline $\begin{array}{l}\text { - from the main operating ac- } \\
\text { tivities }\end{array}$ & 48156 & 11075 & -37081 & -77 & -37081 & $\mathrm{x}$ \\
\hline $\begin{array}{l}\text { from other operating } \\
\text { activities }\end{array}$ & 2515 & 1623 & -892 & $-35,47$ & -892 & $\mathrm{x}$ \\
\hline $\begin{array}{l}\text { 12. Expenditures from activi- } \\
\text { ties before taxation, incl.: }\end{array}$ & 65968 & 29933 & -36035 & $-54,62$ & $\mathrm{x}$ & -36035 \\
\hline $\begin{array}{l}\text { - from the main operating ac- } \\
\text { tivities }\end{array}$ & 62196 & 28271 & -33925 & $-54,55$ & $\mathrm{x}$ & -33925 \\
\hline $\begin{array}{l}\text { - from other operating } \\
\text { activities }\end{array}$ & 3711 & 1662 & -2049 & $-55,21$ & $\mathrm{x}$ & -2049 \\
\hline - from financial activities & $\mathrm{x}$ & $\mathrm{x}$ & $\mathrm{x}$ & $\mathrm{x}$ & $\mathrm{x}$ & $\mathrm{x}$ \\
\hline - from other activities & 61 & 53 & -8 & $-13,11$ & $\mathrm{x}$ & -8 \\
\hline
\end{tabular}

* calculated by the authors on the basis of financial statements and on the basis of $[21,23]$

In the table. 4 first-order factors have been given, but conducting in-depth factor analysis of the formation of financial results of the enterprise requires a more detailed analysis of the factors of the second and third order - the detailing of costs and income of individual activities and individual articles, directions of formation and detailing of these articles into components.

Conclusions and prospects of the further investigations. As a result of the conducted research of the method of analysis of financial results in modern conditions of functioning of enterprises it can be noted that:

- there are differences between national and international normative documents regarding the definition of the essence and formation of the financial result of the enterprise in the financial statements. Thus, according to NP (C) BO 1, profit is the amount by which income exceeds its associated costs, and losses are the excess of the amount of expenses over the amount of income for which these expenses are incurred but in respect of IAS 1 «entroduction of the financial statement», profit or loss is the total income minus costs excert components of other comprehensive income. The study of IAS 1 and IAS 1 has shown that the stages of formation of the final result (profit or loss) by these regulatory documents differ, but in Ukraine the process of harmonization of national regulatory documents controlling the accounting and financial reporting preparation with international ones takes plase which is a positive trend;

- the most common method of analysis of financial results of the enterprise is profitability analysis, profit (loss) analysis and factor analysis, but the least used method is the marginal analysis method and CVR analysis;

- the most scientists, when analyzing the 
financial results of an enterprise's activity, focus their attention, as a rule, on the analysis of the financial result from the main operating activity, which is not expedient, since the positive financial result from the given activity may be reduced due to losses from other activities;

- the conducted research has confirmed the need for analysis of financial results by a comprehensive methodological approach, which covers the analysis of the composition, structure, dynamics of income and expenses of the enterprise, analysis of the formation, structure and dynamics of changes in the financial results of the enterprise, both in general and by individual types, factor analysis of formation of financial results by using additive model taking into account the factors of the first, second and third order, analysis of profitability (products, production, entity makes it possible to develop directions of increase of positive financial result.

\section{References}

1. Mochernyi, S. V. (2000). Ekonomichna entsyklopediia (Vol. 1). Kyiv: Vydavnychyi tsentr «Akademiia».

2. Ostap'iuk, N. A. (2011). Metodyka otsinky finansovoho stanu pidpryiemstva v umovakh infliatsii. Visnyk ZhDTU, (1 (55), 127-129.

3. Antoniuk, O. P. (2016). Konspekt lektsii z kursu «Analiz hospodarskoi diialnosti» dlia bakalavriv napriamu pidhotovky 6.030509 dennoi ta zaochnoi formy navchannia. Odesa: ONAKhT.

4. Voronko, O. S., \& Shtepa, N. P. (2012). Ekonomichnyi analiz. Lviv: «Novyi Svit-2000».

5. Antoniuk, O. P., Stupnytska, T. M., \& Kuprina, N. M. (2015). Ekonomichnyi analiz (3 (vypravlene i dopovnene). Lviv: «Mahnoliia 2006».

6. Hrabovetskyi, B. Ye., \& Shvarts, I. V. (2011). Finansovyi analiz ta zvitnist. Vinnytsia: VNTU.

7. Lytvyn, B. M., \& Stelmakh, M. V. (2008). Finansovyi analiz. Kyiv: «Khai-Tek Pres».

8. Boliukh, M. A., Burchevskyi, V. Z., \& Horbatiuk, M. I. (2003). Ekonomichnyi analiz. Kyiv: KNEU.

9. Chernysh, S. S. (2010). Ekonomichnyi analiz. Kyiv: Tsentr uchbovoi literatury.

10. Mnykh, Ye. V., \& Barabash, N. S. (2014). Finansovyi analiz. Kyiv: Kyiv. nats. torh.-ekon. un-t.

11. Kovalchuk, I. V. (2008). Ekonomika pidpryiemstva. Kyiv: Znannia.

12. Kindratska, H. I., \& Bilyk, M. S. (2008). Ekonomichnyi analiz. (A. H. Zahorodnii, Ed.) (3 (pererob. i doprats.). Kyiv: Znannia.

13. Bilyk, M. D. (2014). Finansovyi analiz (2nd ed.). Kyiv: KNEU.

14. Hadzevych, O. I. (2007). Osnovy ekonomichnoho analizu i diahnostyky finansovo-hospodarskoi diialnosti pidpryiemstva. Kyiv: Kondor.

15. Herasym, P. M., Zhuravel, H. P., \& Khomyn, P. Ya. (2003). Finansovyi, upravlinskyi i podatkovyi oblik u hospodarskykh tovarystvakh (Vat, Zat, Tov, Pop, Pap). Ternopil.

16. Goriczkaya, N. G. (2002). Osobennosti buxgalters`kogo ucheta v sovremenny`x usloviyax. Kyiv: Redakciya gazety` «Buxgalteriya. Nalogi. Biznes».

17. Sheremet, O. O. (2005). Finansovyi analiz. Kyiv: Kondor.

18. Ostap'iuk, N. A. (2011). Metodyka otsinky finansovoho stanu pidpryiemstva v umovakh infliatsii. Visnyk ZhDTU, (1 (55), 127-129.

19. Brukhanskyi, R. F., \& Skyrpan, O. P. (2014). Bukhhalterskyi oblik. Ternopil: TNEU.

20. Karmazin, V. A., \& Savytska, O. M. (2007). Ekonomichnyi analiz. Kyiv: Znannia.

21. Kuprina, N. M., \& Terepenchuk, V. V. (2010). Osoblyvosti ekonomichnoho analizu finansovykh rezultativ diialnosti promyslovoho pidpryiemstva. Naukovyi Visnyk, (20 (121), 91-100.

22. Kuprina, N. M. (2007). Otsinka vplyvu faktoriv na zminu rentabelnosti oborotnoho kapitalu. Ekonomika: Problemy Teorii Ta Praktyky, 2(228), 368-373.

23. Kuprina, N. M., \& Terepenchuk, V. V. (2010). Faktornyi analiz finansovykh rezultativ vid zvychainoi diialnosti promyslovoho pidpryiemstva. Ekonomika: Problemy Teorii Ta Praktyky, 1(266), 25-36.

24. Zahalni vymohy do finansovoi zvitnosti: Natsionalne polozhennia (standart) bukhhalterskoho obliku 1 «Zahalni vymohy do finansovoi zvitnosti» vid 07.02.2013 №73 za stanom na 08.02.2014 r.. (2014). Retrieved June 1, 2019, from https://buhgalter911.com/normativnaya-baza/instr-plan-rah/standart-buhgalterskogo/nacionalynepologhennya-standartu-1021081.html

25. Podannia finansovoi zvitnosti: Mizhnarodnyi standart bukhhalterskoho obliku 1 «Podannia finansovoi zvitnosti» za stanom na $2005 \quad$ r.. (2005). Retrieved June 1, 2019, from https://buhgalter911.com/public/uploads/msfo/2019/IAS\%2001_ukr19.pdf 


\section{Куприна Н.M.}

кандидат экономических наук, доцент кафедра учета и аудита E-mail:k.natali@ @ukr.net ORCID ID: 0000-0003-4645-545X

\author{
Володина Е.П. \\ ассистент \\ кафредра иностранных языков \\ E-mail: completeness7@mail.ru
}

\author{
Завацкая Ю.В. \\ студентка 2 курса с сокращенным сроком обучения степени «Бакалавр» \\ факультет экономики бизнеса и контроля \\ Одесская национальная академия пищевых технологий \\ ул. Канатная, 112, г. Одесса, Украина, 65039 \\ E-mail: juliaz2317@gmail.com
}

\title{
ОСОБЕННОСТИ АНАЛИЗА ФИНАНСОВЫХ РЕЗУЛЬТАТОВ ДЕЯТЕЛЬНОСТИ ПРЕДПРИЯТИЯ В СОВРЕМЕННЫХ УСЛОВИЯХ
}

Целью исследования является изучение подходов к проведению экономического анализа финансовых результатов деятельности предприятия в научных публикациях и формирования фринансового результата в соответствии с НП(С)БУ 1 и М(С)БУ 1, а также фрормирование комплексного подхода проведения экономического анализа финансовых результатов деятельности предприятия с учетом современных условий его функционирования и обеспечения эффективности деятельности.

В статье проведено исследование подходов к методике проведения анализа финансовых результатов деятельности предприятия в работах ученых и публикациях, имеющих практическую направленность, а также в соответствии с национальными и международными Положениями (стандартами) бухгалтерского учета, регулирующими порядок их формирования и отражения в фринансовой отчетности. Исследование показало, что наиболее распространенными в методике анализа финансовых результатов деятельности предприятия является анализ рентабельности, анализ формирования прибыли (убытка) и фракторный анализ, но наименее используемыми направлениями является метод маржинального анализа и CVP-анализ, однако большинство ученых при анализе финансовых результатов деятельности предприятия акцентируют внимание, как правило, на анализе фринансового результата от основной операционной деятельности, что не является целесообразным, так как положительный финансовый результат от данного вида деятельности может быть уменьшен за счет убытка от других его видов.

Проведен анализ финансовых результатов деятельности предприятия по материалам финансовой отчетности предприятия пищевой промышленности за три года с фракторным анализом их формирования с использованием аддитивной модели. Предложено применение комплексного методического подхода к проведению анализа фринансовых результатов деятельности предприятия, охватывающий анализ состава, структуры, динамики доходов и расходов деятельности предприятия, анализ формирования, структуры и динамики изменений финансовых результатов деятельности предприятия, как в целом так и по отдельным видам, факторный анализ формирования финансовых результатов с использованием аддитивной модели с учетом факторов первого, второго и третьего порядка, анализ рентабельности (продукции, производства, капитала) предприятия, позволяет разработать направления увеличения положительного его финансового результата.

Ключевые слова: финансовые результаты деятельности предприятия, виды деятельности предприятия, прибыль, убыток, методика экономического анализа, факторный анализ, аддитивная факторная модель, комплексный методический подход.

Купріна Н.М.

кандидат економічних наук, доцент кафедра обліку та аудиту

E-mail: k.natali_@ukr.net ORCID ID: 0000-0003-4645-545X
Володіна О.П. асистент кафедра іноземних мов E-mail: completeness7@mail.ru

\section{Завацька Ю.В.}

студентка 2 курсу зі скороченим терміном навчання ступеню «Бакалавр» факультет економіки бізнесу і контролю

Одеська національна академія харчових технологій вул. Канатна, 112, м. Одеса, Україна, 65039 E-mail: juliaz2317@gmail.com

\section{ОСОБЛИВОСТІ АНАЛІЗУ ФІНАНСОВИХ РЕЗУЛЬТАТІВ ДІЯЛЬНОСТІ ПІДПРИЄМСТВА В СУЧАСНИХ УМОВАХ}

Метою дослідження $€$ вивчення підходів до проведення економічного аналізу фінансових результатів діяльності підприємства в наукових працях і фрормування фінансового результату відповідно 
до НП(С)БО 1 та М(С)БО 1, а також фрормування комплексного підходу здійснення економічного аналізу фінансових результатів діяльності підприємства з урахуванням сучасних умов його функціонування та забезпечення ефективності діяльності.

В статті проведено дослідження підходів до методики проведення фінансових результатів діяльності підприємства в наукових працях і працях, які мають практичну спрямованість, а також відповідно до національних та міжнародних Положень (стандартів) бухгалтерського обліку, що регулюють порядок їх формування та відображення у фінансовій звітності. Дослідження показало, що найбільш розповсюдженим в методиці аналізу фінансових результатів діяльності підприємства $є$ аналіз рентабельності, аналіз формування прибутку(збитку) та фракторний аналіз, але найменш використовуваними його напрямами є метод маржинального аналізу та CVP-аналіз, але більшість вчених при аналізі фінансових результатів діяльності підприємства акцентують увагу, як правило, на аналізі фрінансового результату від основної операційної діяльності, що не є доцільним, тому що позитивний фінансовий результат від даного виду діяльності може бути зменшений за рахунок збитку від інших його видів.

Проведено аналіз фінансових результатів діяльності підприємства за матеріалами фрінансової звітності підприємства харчової промисловості за три роки з факторним аналізом їх формування з використанням адитивної моделі. Запропоновано застосування комплексного методичного підходу до проведення аналізу фінансових результатів діяльності підприємства, який охоплює аналіз складу, структури, динаміки доходів та витрат діяльності підприємства, аналіз формування, структури та динаміки змін фінансових результатів діяльності підприємства, як загалом так й за окремими видами, фракторний аналіз формування фрінансових результатів за використання адитивної моделі з урахуванням факторів першого, другого та третього порядку, аналіз рентабельності (продукції, виробництва, капіталу) підприємства, що дозволяє розробити напрями збільшення позитивного його фінансового результату.

Ключові слова: фінансові результати діяльності підприємства, види діяльності підприємства, прибуток, збиток, методика економічного аналізу, факторний аналіз, адитивна фракторна модель, комплексний методичний підхід.

\section{Література}

1. Мочерний С.В. Економічна енциклопедія: у 3т. Т. 1. К.: Видавничий центр «Академія», 2000.864 с.

2. Остап'юк Н.А. Методика оцінки фінансового стану підприємства в умовах інфляції. Вісник ЖДТУ. 2011. № 1(55). С. 127-129.

3. Антонюк О.П. Конспект лекцій з курсу «Аналіз господарської діяльності» для бакалаврів напряму підготовки 6.030509 денної та заочної форми навчання. Одеса, ОНАХТ, 2016. 70 с.

4. Воронко О.С., Штепа Н.П. Економічний аналіз: навч. посіб. Львів: «Новий Світ-2000», 2012. 279 с.

5. Антонюк О.П., Ступницька Т.М., Купріна Н.М. Економічний аналіз (практикум): навч. посіб.: 3 -ге вид., виправлене і доповнене. Львів: «Магнолія 2006», 2015. С. 156-318.

6. Грабовецький Б. С., Шварц І.В. Фінансовий аналіз та звітність: навч. посіб. Вінниця: ВНТУ, 2011. $281 \mathrm{c}$.

7. Литвин Б. М., Стельмах М.В. Фінансовий аналіз: навч. посіб. К.: «Хай-Тек Прес», 2008. 336 с.

8. Болюх М.А., Бурчевський В.З., Горбатюк М.І. Економічний аналіз: навч. посіб. К.: КНЕУ, 2003. $556 \mathrm{c}$.

9. Черниш С.С. Економічний аналіз: навч. посіб. К.: Центр учбової літератури, 2010. 312 с.

10. Мних С.В., Барабаш Н.С. Фінансовий аналіз: підручник. К.: Київ. нац. торг.-екон. ун-т, 2014. 536 с.

11. Ковальчук І.В. Економіка підприємства: навч. посіб. К.: Знання, 2008. 679 с.

12. Кіндрацька Г.І., Білик М.С., Загородній А.Г. Економічний аналіз: підручник / за ред. проф. А.Г. Загороднього. 3-тє вид., перероб. і допрац. К: Знання, 2008. 487 с.

13. Фінансовий аналіз: навч.посіб. / Білик М.Д. та ін. 2-ге вид. К.: КНЕУ, 2014. 592 с.

14. Гадзевич О.І. Основи економічного аналізу і діагностики фінансово-господарської діяльності підприємства: навч. посіб. К.: Кондор, 2007, С.5-14

15. Герасим П.М. Журавель Г.П., Хомин П.Я. Фінансовий, управлінський і податковий облік у господарських товариствах (ВАТ, ЗАТ, ТОВ, ПОП, ПАП): навч. посіб. Тернопіль, 2003. С. 335-340.

16. Горицкая Н.Г. Особенности бухгалтерського учета в современных условиях: навч. посіб. К.: Редакция газеты «Бухгалтерия. Налоги. Бизнес», 2002. С. 196-197.

17. Шеремет О.О. Фінансовий аналіз: навч. посіб. К.: Кондор, 2005. С. 53-57

18. Остап’юк Н.А. Методика оцінки фінансового стану підприємства в умовах інфляції. Вісник ЖДТУ. 2011. № 1(55). С. 127-129.

19. Бруханський Р.Ф., Скирпан О.П. Бухгалтерський облік: навч. посіб. Тернопіль: ТНЕУ, 2014. С. 354 -

371.

20. Кармазін В.А., Савицька О.М. Економічний аналіз: практикум. К. : Знання, 2007. 255 с. 
21. Купріна Н.М., Терепенчук В.В. Особливості економічного аналізу фінансових результатів діяльності промислового підприємства // Науковий вісник. Одеський державний університет. Всеукраїнська асоціація молодих науковців. Науки: економіка, політологія, історія. Одеса, 2010. №20(121). С. 91-100

22. Купріна Н.М. Оцінка впливу факторів на зміну рентабельності оборотного капіталу. Економіка: проблеми теорії та практики: зб. наук. праць. Дніпропетровськ, 2007. Вип. 228, Т.2. С. 368-373

23. Купріна Н.М., Терепенчук В.В. Факторний аналіз фінансових результатів від звичайної діяльності промислового підприємства. Економіка: проблеми теорії та практики: зб. наук. праць. Дніпропетровськ, 2010. Вип. 266, Т.1. С. 25-36.

24. Загальні вимоги до фінансової звітності: Національне положення (стандарт) бухгалтерського обліку 1 «Загальні вимоги до фінансової звітності»: затв. наказом Мінфіну від 07.02.2013 №73 за станом на 08.02.2014 p. https://buhgalter911.com/normativnaya-baza/instr-plan-rah/standart-buhgalterskogo/nacionalyne-pologhennyastandartu-1021081.html (дата звернення: 01.06.2019).

25. Подання фінансової звітності: Міжнародний стандарт бухгалтерського обліку 1 «Подання фінансової звітності» за станом на 2005 р. URL: https://buhgalter911.com/public/uploads/msfo/2019/IAS\%2001_ukr19.pdf (дата звернення: 01.06.2019).

Стаття надійшла 1.07.2019 Стаття прийнята до друку 15.07.2019 Доступно в мережі Internet 16.10.2019

Цитування згідно ДСТУ 8302:2015

Kuprina N., Volodina O., Zavatska Yu. Features of the analysis of financial results of the enterprise activities in modern conditions // Food Industry Economics. 2019. Vol.11, Issue 3. P. 40-49. doi: 10.15673/fie.v11i3.1460

Cite as APA style citation

Kuprina, N., Volodina, O., \& Zavatska, Yu. (2019). Features of the analysis of financial results of the enterprise activities in modern conditions. Food Industry Economics, 11(3), 40-49. doi: 10.15673/fie.v11i3.1460 